\title{
頭頸部癌手術療法のエビデンスと 多施設共同研究に向けた今後の方策
}

\author{
1) 慶應義塾大学医学部耳鼻咽喉科 \\ 2) 国立病院機構東京医療センター耳鼻咽喉科

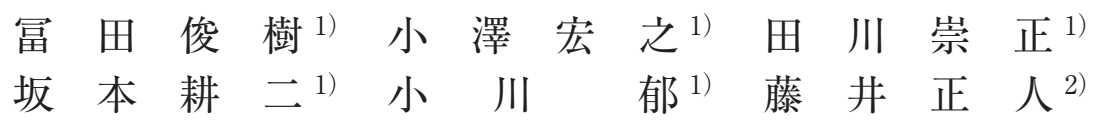

\begin{abstract}
論文要旨
頭頸部進行癌の治療において手術は重要な役割を果たしているがエビデンスが不明確な手術は多い。海外の 多施設共同研究により得られた頭頸部癌手術療法のエビデンスを検証し, 本邦において今後どのような共同研 究を行うべきか考察した。手術を含む多施設共同研究は, 手術療法と他の治療法の比較, 手術療法同士の比 較, 手術を加えるか否か, 術後補助療法の比較に分類される。手術と化学放射線療法の比較, 全頸部郭清術と 選択的頸部郭清術の比較, 化学放射線療法後の計画的頸部郭清術, 術後照射と術後化学放射線療法の比較研究 について考察した。

共同研究を行うためには頭頸部外科医，放射線科医，腫瘍内科医の間で共通の言語を持つ必要がある。その ためには切除不能の定義を明確にすること, 米国の NCCN（National Comprehensive Cancer Network）ガイ ドラインなどを参考にすることが重要である。
\end{abstract}

キーワード : 頭頸部癌, 手術, エビデンス, 多施設共同研究, 臨床試験

\section{はじめに}

頭頸部進行癌の治療において手術は重要な役割を果たし ているが, 個々の手術がどのようなエビデンスに基づいて 選択されているのか疑問を感じることは多い。頭頸部進行 癌に対する化学療法や放射線療法の多施設共同研究は数多 く行われ高いレベルのエビデンスが導き出されているが, 手術に関する多施設共同研究は少なくエビデンスレベルも 低いものが多い。手術を多施設共同研究に組み入れるこ とは難しいことのように思えるが, JCOG（Japan clinical oncology group）の食道がんグループや胃がん外科グルー プなどは手術を組み入れた多施設共同研究を行い世界に向 けて情報を発信している1,2)。

本稿ではこれまでに報告された頭頸部癌手術療法を含む 多施設共同研究のエビデンスを検証し, 多施設共同研究に 向けた今後の方策について頭頸部外科医の視点から考察す る。

\section{切除不能の定義}

手術が多施設共同研究のプロトコールに入るか否かを検 討するうえで切除不能の定義を明確にする必要がある。ま た化学療法や放射線療法の目的は切除不能例においては生

別刷請求先： $\mathbf{\top} 160-8582$ 東京都新宿区信濃町 35 慶應義塾大学医学部耳鼻咽喉科 冨田 俊樹
存期間を延長することであるが, 切除可能例においては生 存率を落とさずに音声言語機能や黇下機能を温存すること である ${ }^{3)}$ 。従って多施設共同臨床試験のプロトコールを組 む際には手術を含むか否かに関わらず切除可能と不能の定 義を明確にすることが重要である。ところが切除不能の基 準は医療施設や頭頸部外科医によって異なる。また手術拒 否, 遠隔転移, 全身合併症などの理由で手術不適応となる 症例を切除不能に含めるのか否かも明確にする必要があ る。ランダム化比較試験に関する論文で切除不能の定義を 明確に示したものは少ない。Adelstein らは部位別に切除 不能の診断基準を定めており, (1)下咽頭癌 : 後壁の正中を 越えているか頸椎に癒着, (2)喉頭癌 : 周囲の筋か皮膚に直 接浸潤しているか声門下に $3 \mathrm{~cm}$ を超える浸潤あり, (3) 腔癌: 機能的再建が不可能な広範囲に浸潤, (4)舌根癌 : 舌 骨周囲に浸潤しているか推奨された舌全摘を拒否, (5)口蓋 扁桃癌 : 翼突筋または頸部軟組織に直接浸潤しているか中 咽頭後壁正中を超えている，などとしている。さらに頸部 リンパ節が頸動脈, 乳突部, 頭蓋底, または頸椎に癒着し ている場合も切除不能としている。以上の基準に基づいて 頭頸部外科医が個々の症例について切除不能か否か慎重に 評価している。内科的理由で手術に適さない場合, 遠隔転 移あり, 手術拒否は切除不能に含めない。ただし舌全摘に ついては手術を拒否した場合でも切除不能としている フランスの多施設共同研究においてもやはり頭頸部外科医 が個々の症例について切除不能か否か評価している。切除 不能の診断基準として, 腫瘍の軟部組織, 頸椎, 頭蓋底へ 
表 1 切除不能の定義

原発巣または頸部リンパ節転移病変が

総頸動脈または内頸動脈に浸潤

頭蓋底に浸潤

深頸筋膜，椎前筋に浸潤

舌喉頭全摘が唯一の術式となってしまう場合

内科的理由による手術不適応や手術拒否は除外

の浸潤，舌咽頭喉頭全摘術が唯一の充分な術式である場合 としている。また内科的理由による手術不適応は除外して いる5)。いずれの報告においても音声言語機能を培失し味 覚障害や嬹下障害をもたらす舌喉頭全摘術は, oncologic に切除可能であっても患者にとって受け入れがたい手術で あり切除不能と同等に扱うべきであるとしている。

本邦における報告 6 も合わせると切除不能の定義は表 1 のようにまとめられる。舌喉頭全摘術の適応症例が切除不 能の基準に含まれるのは奇異であるが，機能的に受け入れ られがたい手術は手術不能と同等であるという解釈は本邦 でも徐々に浸透していくものと思われる。

\section{頭頸部癌手術療法のエビデンス}

多施設共同研究における手術の組み入れ方としては，1) 手術療法と他の治療法の比較, 2) 手術療法同士の比較（異 なる術式の比較)，3）集学的治療の中で手術を加えた場合 と加えない場合の比較，4）手術を同様に行った群におけ る他の治療法の比較（術後補助療法の比較）などの形式 に分類される。これらの分類ごとに PubMed（1990-2006） で “hnscc”, “clinical trial”などをキーワードとして文献 検索し，エビデンスレベルが高いもの，歴史的に重要なも のを選択した。エビデンスレベルの分類にはさまざまなも のがあるがオックスフォード EBM センターの提案を参考 にした (表 2) 7)。

1）手術療法と他の治療法の比較

手術療法と他の治療法の比較研究には，手術と化学放射 線療法の比較, あるいは手術＋術後照射と化学放射線療 法の比較がある。アメリカの RTOG（Radiation therapy oncology group）は切除可能な進行喉頭癌に対する喉頭温 存を目的としたランダム化比較試験を 1991 年から開始し 2003 年に報告した ${ }^{8)}$ 。この RTOG 91-11 は III， IV 期の喉 頭癌 を対象とした導入化学療法 $(\mathrm{CDDP}+5-\mathrm{FU})+$ 放射 線療法, CDDP 併用の化学放射線療法, 放射線療法（+計 画的頸部郭清術）の 3 群のランダム化比較試験である。遠 隔転移率は放射線療法（+計画的頸部郭清術）群が有意 に高いものの 5 年全生存率では 3 群間に有意差を認めず, 喉頭温存率は化学放射線療法群が有意に高かった。結論と して T3-4 N0 声門上癌および T3 any N 声門癌で喉頭温存 を希望する場合は CDDP 併用の化学放射線療法が標準的 治療であると述べている（レベル $1 \mathrm{~b}$ のエビデンス）。これ に対してWeinstein らは経口的内視鏡切除術や喉頭部分切
表 2 治療研究のエビデンスレベル

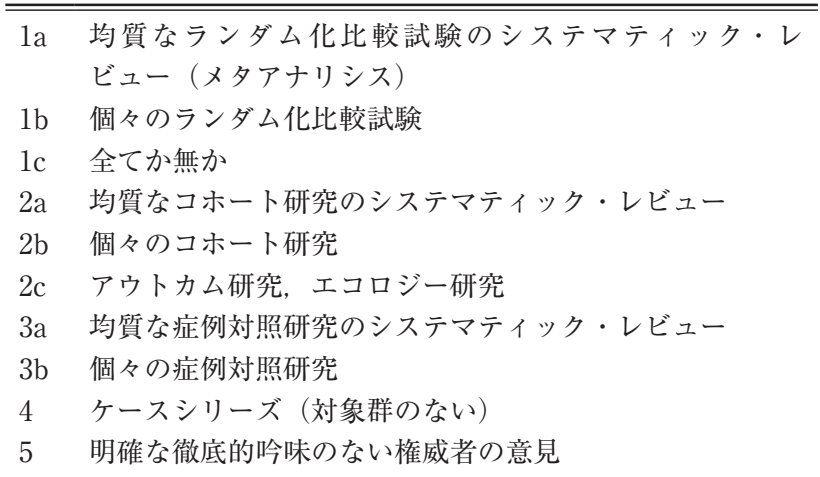

出典 : Oxford Centre for Evidence-based Medicine Levels of Evidence (May 2001)

http://www.cebm.net/levels_of_evidence.asp

除術などの機能温存喉頭手術が優れた成績を得ていること を主張し機能温存手術を無視したRTOG 91-11に反論し ている。しかし RTOG 91-11の Forastiere は機能温存喉 頭手術が他の臟器温存治療より優れていることを証明した ランダム化比較試験はないと返答し機能温存喉頭手術を支 持するエビデンスレベルが低いことを指摘している9)。 N Engl J Med 誌上で繰り広げられたこの討論からは手術と 化学放射線療法の比較にはランダム化比較試験が望ましい

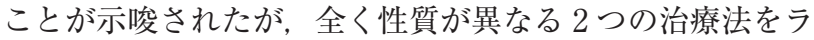
ンダム化試験に持ち込むことは倫理的な観点から難しいこ とが予想される。このような問題に対し手術のエビデンス については特殊性を考慮すべきという意見もある。 $\mathrm{EBM}$ において “Best available evidence”という概念があるよ うにすべてのエビデンスがランダム化比較試験に基づく必 要はない。症例登録に基づく観察研究つまりコホート研究 や症例対象研究の意義が過小評価されているが, 特に外科 領域においては観察研究の意義を見直す必要があるかもし れない10)。

手術と化学放射線療法のランダム化比較試験は難しいと 思われてきたが，シンガポール国立がんセンターが切除可 能な頭頸部癌に対し手術＋術後照射と化学放射線療法の ランダム化比較試験を行った。化学放射線療法群に割り付 けられた症例の一部には計画的頸部郭清術や救済手術が行 われている。 3 年無病生存率は 2 群間に有意差を認めず, 喉頭と下咽頭は他の部位に比べ臟器温存率が有意に高いこ とが示された。結論として手術＋術後照射は依然として 有効な治療法であるが，喉頭癌と下咽頭癌に対しては臟器 温存を目的に化学放射線療法を試みるべきと述べている (レベル $1 \mathrm{~b}$ のエビデンス) $)^{11) 。}$

2) 手術療法同士の比較（異なる術式の比較）

異なる術式の比較としては頭頸部癌手術の基本である 頸部郭清術が興味深い。N0 症例に対する予防的頸部郭清 術に関してブラジルの頭頸部癌研究グループが T2-T4 N0 の口脉癌，喉頭癌を対象としてそれぞれ Selective neck dissection（SND）群と Modified radical neck dissection 
表 3 NCCN コンセンサスのカテゴリー

\begin{tabular}{|c|c|}
\hline カテゴリー 1 & $\begin{array}{l}\text { 高いレベルのエビデンスに基づいて，その推奨が適切であるとする } \\
\mathrm{NCCN} \text { の統一見解がある }\end{array}$ \\
\hline カテゴリー $2 \mathrm{~A}$ & $\begin{array}{l}\text { 臨床経験を含む低いレベルのエビデンスに基づいて, その推奨が適切で } \\
\text { あるとする NCCN の統一見解がある }\end{array}$ \\
\hline カテゴリー2B & $\begin{array}{l}\text { 臨床経験を含む低いレベルのエビデンスに基づいて, NCCN 内で統一さ } \\
\text { れていない (が大きな意見の不一致はない) 見解がある }\end{array}$ \\
\hline カテゴリー 3 & その推奨が適切であるとするには NCCN 内で大きな意見の不一致がある \\
\hline
\end{tabular}

出典 : NCCN Clinical Practice Guidelines in Oncology ${ }^{\mathrm{TM}-}$ v. 1. 2006 head and neck cancers. http://www.nccn.org/professionals/physician_gls/PDF/head-and-neck.pdf

（MRND）群に分けたランダム化比較試験を行った ${ }^{12,13)}$ 。 術中迅速病理で転移陽性と判明した場合はSND 群でも MRND に変更するというプロトコールであったが，永久 標本において転移陽性だった症例も $20 \%$ しか術中迅速で は陽性と判明せずほとんどの症例は最初に割り付けられた 術式が行われた。また転移陽性例は術後照射が追加され た。2 群間で再発率， 5 年全生存率に有意差は認めず，口 腔癌ではSND 群において合併症は有意に少なかった。結 論として口腔癌, 喉頭癌において N0の予防的郭清には SND が推奨されると述べている（レベル $1 \mathrm{~b}$ のエビデン ス ${ }^{12,13)}$ 。

$\geqq \mathrm{N} 1$ における SND と MRND のランダム化比較試験 はこれまで報告されていない。Gourin はミN1において SND は十分かという疑問に対しコホート研究のシステマ ティック・レビューを行った。被膜外浸潤がない $\mathrm{pN1}$ に おいては SND が適切であるが，被膜外浸潤陽性か N2b 以 上の場合は SND では不十分であり術後照射を行うべきと している (レベル 2a のエビデンス $)^{14)}$

ミN1 における SND と MRND のランダム化比較試験に ついてはさまざまな困難が予想される。本邦における頸部 郭清術の術式には施設差の存在が疑われ均一化が求められ ている15)。また後述するがリンパ節被膜外浸潤例には術後 化学放射線療法を行うべきというエビデンスもあるため, 単純に手術療法のみを比較することは困難となってきてい る。さらに切除可能なステージ III, IV 期の中咽頭癌, 下咽 頭癌, 喉頭癌においては頸部リンパ節病変に対しても化 学放射線療法が行われることが多くなり N1に関しては頸 部郭清術は不要とする意見が多い16)。N2，N3 については 化学放射線療法後に行う Planned neck dissection (PND, 計画的頸部郭清術）において SND と MRNDを比較する ことは興味深いが, PND そのものに意義があるか疑問視 する意見もあるためランダム化比較試験を計画しにくい。

3）手術を加えるか否か

多施設共同研究における手術の組み入れ方として, 手術 を加える群と加えない群を比較し手術の上乗せ効果を検証 する研究がある。これには化学放射線療法後に PND を追 加するか否かという研究がある。 Brizel らは N2 以上の中
咽頭癌, 下咽頭癌, 喉頭癌, 口腔癌で CDDP + 5-FU の 化学放射線療法を施行後に原発巣が CR を得た症例にお いて PNDを施行した群と施行しなかった群を比較してい る。化学放射線療法によって頸部リンパ節が臨床的に CR と判定された症例の 4 年全生存率は PND 施行群が非施行 群に比較して有意に良好であった（レベル $2 \mathrm{~b}$ のエビデン

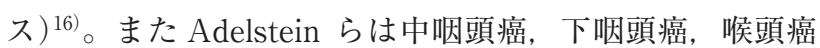
を対象として CDDP + 5-FU の化学放射線療法後に PND を施行した群と施行しなかった群を比較している。5 年頸 部制御率は PND 施行群が非施行群に比較して有意に良好 であった (レベル $2 \mathrm{~b}$ のエビデンス ${ }^{17)}$ 。このように $\mathrm{PND}$ に関してはランダム化比較試験の報告は見られないものの コホート研究のエビデンスは蓄積されつつある。PNDに ついてより高いレベルのエビデンスを得るためには，部 位, 化学放射線療法のレジメ, PNDの時期や術式を統一 したランダム化比較試験が必要である。

\section{4）術後補助療法の比較}

多施設共同研究のひとつに根治手術を同様に行ったうえ で術後補助療法を比較する研究がある。RTOG と EORTC (European organisation for research and treatment of cancer）は根治手術を行った頭頸部進行癌の再発高危険 度症例に対する術後化学放射線療法の有用性を検証する 研究を同時期に行った ${ }^{18,19)}$ 。再発高危険度症例の選択基準 としてRTOG 研究 では被膜外浸潤, 切除断端陽性, 2 個 以上のリンパ節転移とし, EORTC 研究ではリンパ節外浸 潤, 切除断端陽性, 傍神経浸潤, 脈管浸潤, 口腔・中咽頭 癌のレベル $\mathrm{I}, \mathrm{V}$ リンパ節転移, III, IV 期としている。こ れらの基準を満たした症例を単独照射群と化学放射線療 法 (CDDP $100 \mathrm{mg} / \mathrm{m}^{2} \times 3$ 回) 群にランダマイズしてい る。RTOG 研究では生存期間に差は見られなかったもの の, 無病生存期間および局所制御率において化学放射線療 法群が単独照射群より有意に優れた成績を得たと報告して いる ${ }^{18)}$ 。またEORTC 研究では生存期間, 無病生存期間と も化学放射線療法群が単独照射群より有意に良好であっ たと報告している ${ }^{19)}$ 。これら 2 つ研究は術後治療におけ る放射線治療への化学療法の上乗せ効果が予後を改善して いることを示唆したものであり N Engl J Med 誌上に同時 
掲載された（レベル 1b のエビデンス）。その後 RTOG と EORTC は再発高危険度選択基準の再分析を行いリンパ節 被膜外浸潤および切除断端陽性が最も重要であると報告し ている20)。

NCCN (National Comprehensive Cancer Network) ガ イドラインが 2005 年版から 2006 年版に改訂された際に, リンパ節被膜外浸潤あるいは切除断端陽性例に対するシ スプラチン併用の術後化学放射線療法は追記された ${ }^{21}$ 。 RTOG と EORTC の研究は放射線科および腫瘍内科主導 であるが，手術を主体とした治療の成績向上を図ったとい う点において頭頸部外科医の視点からも高く評価されるべ きである。

\section{多施設共同研究に向けた今後の方策}

日本では頭頸部癌の症例数は少なく，例えば口腔癌と咽 頭癌を合わせても肺癌の $1 / 7$ 以下，胃癌の $1 / 10$ 以下であ る ${ }^{22)}$ 。高いレベルのエビデンスを導き出すためには多くの 症例数を確保する必要があり，単一施設研究よりも多施設 共同研究が望ましい。その際には放射線科, 腫瘍内科, 頭 頸部外科医が共通の言語を持つ必要がある。そのためには すでに述べたように切除不能の定義を明確すること，また 最新のエビデンスについて共通の認識を持つことが重要で ある。このためには診療ガイドラインが有用であり特に $\mathrm{NCCN}$ クリニカルガイドラインは入手しやすい21。

$\mathrm{NCCN}$ ガイドライン頭頸部癌版は全米の主たる 19 の癌 治療施設から選出された 28 人のパネルメンバー（腫瘍内 科医 7 人, 放射線腫瘍医 6 人, 耳鼻咽喉科あるいは腫瘍外 科医 15 人）によって作成され毎年更新されている。診断, 治療, 治療後の経過観察について流れ図形式で記載されて おり，治療法にはそれぞれどのようなコンセンサスに基づ いているか明記されている。コンセンサスは 3 つのカテゴ リーに分けられ，カテゴリー 1 は高いレベルのエビデンス に基づくコンセンサス，カテゴリー 3 はパネルメンバーの 間でも大きな意見の相違があったものとされている（表 3)。

今後, 多施設共同の臨床試験を構築するためにはカテゴ リー $2 \mathrm{~B}$ やカテゴリー 3 に相当する治療法に注目すべきで ある。手術療法に関しては, 化学放射線療法後の計画的頸 部郭清術や, 頸部郭清術の術式の選択などがカテゴリー $2 \mathrm{~B}$ やカテゴリー 3 とされている。手術療法を含む多施設 共同研究を行うためには様々な困難が予想されるが，共同 研究によって手術療法のエビデンスレベルを高めていくこ とは頭頸部外科医が果すべき責務のひとつである。

\section{まと め}

1. 切除不能を明確に定義することは臨床試験を計画す る上で重要である。

2. 手術療法のエビデンスを検証した。1）手術療法と化 学放射線療法の比較，2）頸部郭清術の術式の比較，3）化 学放射線療法後の計画的頸部郭清術，4）根治手術後の放
射線療法における化学療法の上乗せ効果，を文献的に考察 した。

3. 手術に関する多施設共同研究を計画する際には $\mathrm{NCCN}$ ガイドラインのカテゴリー $2 \mathrm{~B}, 3$ に注目すべきで ある。

本論文の要旨は第 30 回日本頭頸部癌学会（2006 年 6 月 16 日, 大阪）のシンポジウム「頭頸部癌治療における我が国からの科学 的根拠に基づいた情報発信に向けて」において発表した。

\section{文献}

1) Ando N., Iizuka T., Ide H., et al: Surgery plus chemotherapy compared with surgery alone for localized squamous cell carcinoma of the thoracic esophagus: A Japan Clinical Oncology Group Study 9204. J Clin Oncol. 21 : 4592-4596, 2003

2) Sano T., Sasako M., Yamamoto S., et al: Morbidity and Mortality Results From a Prospective Randomized Controlled Trial Comparing D2 and Extended Para-Aortic Lymphadenectomy: Japan Clinical Oncology Group Study 9501. J Clin Oncol. 22 : 2767-2773, 2004

3）藤井正人：Concurrent chemoradiotherapy の役割とエビデ ンス JOHNS 21(1): 31-35, 2005

4) Adelstein D.J., Li Y., Adams G.L., et al: An intergroup phase III comparison of standard radiation therapy and two schedules of concurrent chemoradiotherapy in patients with unresectable squamous cell head and neck cancer. J Clin Oncol. $21: 92-98,2003$

5) Bensadoun R.J., Benezery K., Dassonville O., et al: French multicenter phase III randomized study testing concurrent twice-a-day radiotherapy and cisplatin/5-fluorouracil chemotherapy $(\mathrm{BiRCF})$ in unresectable pharyngeal carcinoma: Results at 2 years (FNCLCC-GORTEC). Int J Radiat Oncol Biol Phys. 64 : 983-994, 2006

6）富田吉信, 上村裕和, 梅野博仁他：根治手術不能症例の診断 と治療 耳鼻 51(補 1)：S51-S60, 2005

7) Oxford Centre for Evidence-based Medicine Levels of Evidence (May 2001) (Accessed July 5, 2006, at http://www. cebm.net/levels_of_evidence.asp)

8) Forastiere A.A., Goepfert H., Maor M., et al: Concurrent chemotherapy and radiotherapy for organ preservation in advanced laryngeal cancer. N Engl J Med. 349 : 2091-2098, 2003

9) Weinstein G.S., Myers E.N., Shapshay S.M., et al: Nonsurgical treatment of laryngeal cancer. N Engl J Med. 350 : 1049-1053 ; author reply 1049-1053, 2004

10）中山健夫, 福原俊一, 小田中徹也 : 新しい診療ガイドライン の作成とエビデンスの調ベ方 EBM ジャーナル 4(5)：512517, 2003

11) Soo K.C., Tan E.H., Wee J., et al: Surgery and adjuvant radiotherapy vs concurrent chemoradiotherapy in stage III/IV nonmetastatic squamous cell head and neck cancer: a randomised comparison. Br J Cancer. 93 : 279-286, 2005

12) Brazilian Head and Neck Cancer Study Group: Results of a prospective trial on elective modified radical classical versus supraomohyoid neck dissection in the management of oral squamous carcinoma. Am J Surg. 176 : 422-427, 1998

13) Brazilian Head and Neck Cancer Study Group: End results of a prospective trial on elective lateral neck dissection vs type III modified radical neck dissection in the management of supraglottic and transglottic carcinomas. Head Neck. 21 : 694-702, 1999

14) Gourin C.G.: Is selective neck dissection adequate treatment for node-positive disease? Arch Otolaryngol Head Neck Surg. 130 : 1431-1434, 2004

15）斉川雅久，岸本誠司，中島 格他：頸部郭清術の手術術式の 
均一化に関する研究 頭頸部癌 32(1)：72-80, 2006

16) Brizel D.M., Prosnitz R.G., Hunter S., et al: Necessity for adjuvant neck dissection in setting of concurrent chemoradiation for advanced head-and-neck cancer. Int J Radiat Oncol Biol Phys. 58 : 1418-1423, 2004

17) Adelstein D.J., Saxton J.P., Rybicki L.A., et al: Multiagent concurrent chemoradiotherapy for locoregionally advanced squamous cell head and neck cancer: mature results from a single institution. J Clin Oncol. 24 : 1064-1071, 2006

18) Cooper J.S., Pajak T.F., Forastiere A.A., et al: Postoperative concurrent radiotherapy and chemotherapy for high-risk squamous-cell carcinoma of the head and neck. N Engl J Med. 350 : 1937-1944, 2004

19) Bernier J., Domenge C., Ozsahin M., et al: Postoperative irradiation with or without concomitant chemotherapy for locally advanced head and neck cancer. N Engl J Med. 350 :
1945-1952, 2004

20) Bernier J., Cooper J.S., Pajak T.F., et al: Defining risk levels in locally advanced head and neck cancers: A comparative analysis of concurrent postoperative radiation plus chemotherapy trials of the EORTC (\#22931) and RTOG (\# 9501). Head Neck $27: 843-850,2005$

21) NCCN Clinical Practice Guidelines in Oncology ${ }^{\mathrm{TM}}-$ v. 1.2006 head and neck cancers. (Accessed July 5, 2006, at http:// www.nccn.org/professionals/physician_gls/PDF/head-andneck.pdf

22) The Research Group for Population-based Cancer Registration in Japan: Cancer Incidence and Incidence Rates in Japan in 1999: Estimates Based on Data from 11 Populationbased Cancer Registries. Jpn J Clin Oncol. 34 : 352-356, 2004 


\title{
Evidence of Head and Neck Surgery and Future Strategy FOR Multi-institutional Studies
}

\author{
Toshiki TOMITA ${ }^{1)}$, Hiroyuki OZAWA ${ }^{1)}$, Takamasa TAGAWA ${ }^{1)}$, \\ Koji SAKAMOTO ${ }^{1)}$, Kaoru OGAWA ${ }^{1)}$, and Masato FUJII ${ }^{2)}$ \\ 1) Department of Otolaryngology, Keio University School of Medicine \\ ${ }^{2)}$ Department of Otolaryngology, National Tokyo Medical Center
}

Although surgery has played an important role in the treatment of advanced head and neck cancer, there are many cases of surgery with inconclusive evidence. We reviewed the evidence of head and neck surgery obtained by multi-institutional studies in foreign countries, and considered the direction to be taken in Japan in the future. We classified the studies into four groups: the comparison of surgery and other treatment methods, the comparison of two surgical methods, the analysis of the added value of some surgery, and the comparison of postoperative treatment. We reviewed the comparison of surgery and chemoradiation, the comparison of comprehensive neck dissection and selective neck dissection, the planned neck dissection after chemoradiation, and the comparison of postoperative radiation and chemoradiation. In order to carry a multiinstitutional study, it is necessary to share a common language among the head and neck surgeons, radiation oncologists and medical oncologists. Clarifying the definition of unresectability and referring to the NCCN (National Comprehensive Cancer Network) clinical practice guideline are important for that purpose.

Key words : head and neck cancer, surgery, evidence, multi-institutional study, clinical trial 